\title{
Development of microbial euendolithic communities: The influence of light and time
}

\author{
MARCOS GEKTIDIS
}

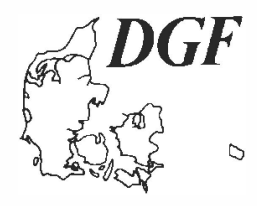

Gektidis, M.: Development of microbial euendolithic communities: the influence of light and time. Bulletin of the Geological Society of Denmark. Vol. 45, pp. 147-150. Copenhagen, 1999-01-30. https://doi.org/10.37570/bgsd-1998-45-18

The importance of euendolithic microbial communities as a palaeontological tool for the reconstruction of ancient sedimentary basin history has been widely ac- knowledged (Golubic et al. 1975, 1984, Vogel et al. 1995, 1996). This tool can be improved by better knowledge of the relationship between modern microendoliths (rock-penetrating microorganisms) and the environmental conditions they thrive in.

The aim of a long-term study conducted on Lee Stocking Island, Bahamas, was to point out factors that control occurrence, distribution and composition of microbial euendolithic populations. The experimental design and first results are published in Radtke 1993, Kiene et al. 1995, Vogel et al. 1996, Gektidis 1997. This paper deals with one aspect of microendolithic development: the progress and change of community structure in time. Microendolithic biocoenoses are excellent bathymetric indicators (Golubic 1975, Gektidis 1997). However their potential use as indicators for different water depths is influenced by the continuous growth of the endolithic communities themselves and the surrounding benthic microflora. This process will have to be taken into consideration when, following a uniformitarian approach, fossil basins are to be reconstructed by analyzing the fossil microendolithic ichno-communities.

Key words: endolith, microbe, light, time, community structure, bathymetry, palaeobathymetry.

M. Gektidis, Geologisch-Paläontologisches Institut, J.-W.-Goethe-Universität, Senckenberganlage 32, D - 60054 Frankfurt am Main, Germany. 10 July 1998.

The present article summarizes results from a longterm study, conducted on Lee Stocking Island, Bahamas since 1992. This is why discussion and conclusions are emphasized rather than a presentation of the data. For a detailed description of the experiments and a profound presentation of the results the reader is referred to Kiene et al. (1995), Vogel et al. (1996) and Gektidis (1997).

\section{Methods}

Experiments conducted around Lee Stocking Island, Bahamas were designed using test blocks of different calcareous substrates. These (4 replicates each) were exposed to different water-depths and recollected at increasing time intervals. The first results of the study are discussed in Kiene et al. (1995), Vogel et al. (1996) and Gektidis (1997)

Three zones were defined for the experiments: the intertidal zone $(\mathrm{N})$, the shallow water zone $(\mathrm{SH})$ and the deep water zone (DW). The substrates were exposed for 6 months and 24 months. After recollection, the substrates were fixed in $5 \%$ formaldehyde with seawater. The euendolithic community was analyzed using standard light-microscope methods.

\section{Results}

Figure 1 shows the composition of the endolithic communities at positions N, SH, and DW. Their development after 6 months and 24 months is compared to epilithic overgrowth. The presentarticle describes only 


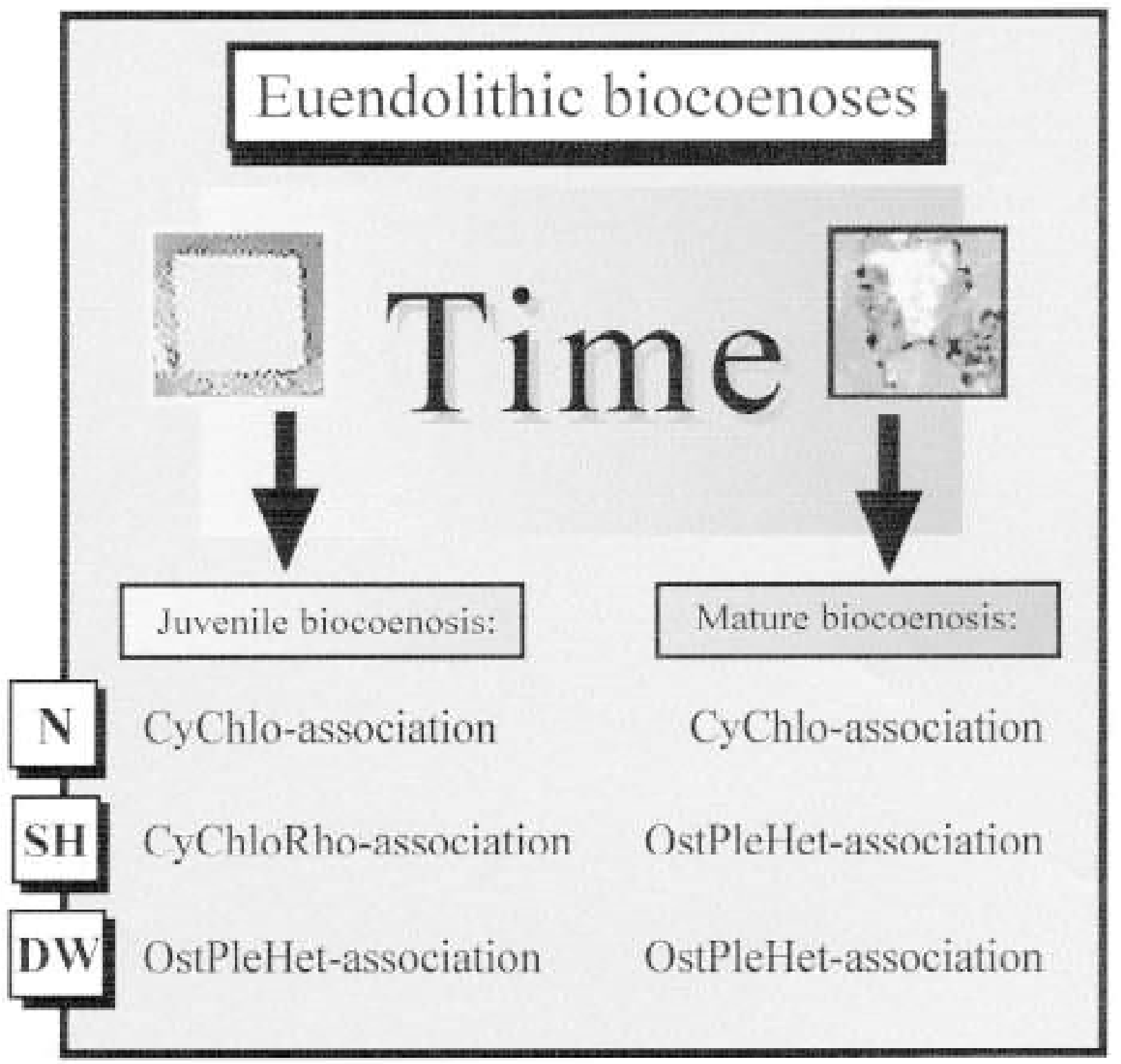

Fig.1. Change in community composition with time. In shallow waters (SH), juvenile biocoenoses consist of cyanobacteria, chlorophytes and rhodophytes, the CyChloRho-association. Here no epilithic algae disturb the endolithic community, symbolized by the clean substrate surface. The mature biocoenosis has changed into an OstPleHet-association, which is characterized by Ostreobium quekettii, Plectonema terebrans and heterotrophic microborers. It developed as a consequence of reduced light availability through epilithic shading (overgrown substrate surface). No change with maturity is seen in the intertidal (N) or deep-water communities (DW).

simplified community patterns of the bathymetric zonation, characterizing the three zones by the dominant groups. For a detailed description of the euendolithic zonation see Gektidis (1997).

After 6 months, a diverse assemblage of cyanobacteria/cyanophytes (Hyella, Mastigocoleus, Solentia, and Hormathonema) inhabits the intertidal zone (N) together with the chlorophyte Phaeophila dendroides. Hereafter this type of association is named CyChlo- association because of the dominance of cyanobacteria/cyanophyta and the occurence of Chlorophyta. Substrates exposed in shallow waters from $2 \mathrm{~m}$ to 30 $\mathrm{m}(\mathrm{SH})$ are infested by chlorophytes (Phaeophila, Ostreobium), the conchocelis stage of a rhodophyte and diverse cyanobacteria/cyanophytes. Therefore this type of association is named CyChloRho-association.

In the deeper waters from $100 \mathrm{~m}$ to $275 \mathrm{~m}$ (DW), the green alga Ostreobium quekettii is the only abun- 
dant photoautotrophic organism. Additionally, the highest DW position at $100 \mathrm{~m}$ depth is inhabited by Plectonema terebrans. Fungal microborers are dominant in DW. The OstPleHet-association stands for the three dominating microendoliths in deeper waters.

After two years, the picture changes. The three positions are less easily recognizable than they were after 6 months. Only the intertidal microendolithic assemblage retains the characteristic dominance of cyanobacteria/cyanophytes. Ostreobium quekettii infests all SH positions and dominates in the deepest one $(30$ $\mathrm{m})$. Zones DW and SH now exhibit similar microendolithic populations.

\section{Conclusion and discussion}

The composition of euendolithic communities that develop after 6 months of exposure (juvenile colonies) is representative for the three different depth zones. Since those communities consist of photoautotrophic organisms, the decrease of light availability with increasing water depth is the controlling factor for the community development. However, light availability not only changes with depth but also with time. The change in community pattern with time, already visible in our experiments after 24 months, hints at a second process, which serves as a controlling factor for community composition. Observations on the development of epilithic organisms can help explain this process. As time passes, epilithic communities start to cover the substrate surface. Their growth influences the development of the underlying euendoliths. More light is filtered out as the epiliths become denser. At the same time, the microendoliths have penetrated as far into the substrate as the decreasing light allows. New species have to cope with the reduced light availability since the only fresh substrate they can bore into is situated under the previous borings. This favours low-light specialists like Ostreobium quekettii or Plectonema terebrans in the long-exposed SH positions. Additional parameters like grazing pressure may also be expected to influence the process of continuous endolithic community change. Le CampionAlsumard et al. (1995) and Chazottes et al. (1995) have conducted similar experiments in French Polynesia. Their findings confirm the tiering effect with time and the dominance of Ostreobium in mature colonies.

Following a uniformitarian approach, fossil communities can serve as a palaeobathymetric tool (Radtke 1991, Glaub 1994, Vogel et al. 1995, 1996). As a consequence of this study, trace communities (ichnocoenoses) in fossil reef environments have to be studied carefully. Fossil community patterns have to be evaluated either as indicators for a certain water depth (juvenile colonies) or as mature communities, where the bathymetric indication is masked. Mature ichno- coenoses still hold the information for a bathymetric classification: the process of infestation can be preserved in the trace-web by tiering (Bromley \& Asgaard 1993). Different tiers resemble different stages, from juvenile to mature trace communities, of microendolithic infestation. The juvenile tier, which most clearly shows the bathymetric level of substrate origination, might be preserved in the fossil record. By analyzing these structures through specialized techniques (castembedding method, Golubic et al. 1983), the history of microendolithic infestation in a substrate can be unraveled and used for palaeobathymetric classification. Other processes, that might be responsible for tiering effects, transportation or sedimentation for example, must be taken into consideration as well. By applying a careful analysis of the fossil community structure, mistakes in palaeobathymetric classification of ancient marine deposits can be avoided.

\section{Dansk sammendrag}

Endolithiske (borende) mikrobe-samfund har været anvendt som værktøj i rekonstruktion af sedimentære bassiners historie. Målet for et længere varende forsøg ved Lee Stocking Island, Bahamas, var at udpege de faktorer som kontrolerer forekomsten, fordelingen og sammensætningen af endolithiske populationer. Denne afhandling omhandler mikroendolithiske samfund-strukturers udvikling og ændring med tiden. Mikroendolithernes potentiale for dybdeindikation påvirkes af deres kontinuerte vækst og væksten af den omgivende benthiske mikroflora. Denne process må tages i betragtning når fossile bassiner skal rekonstrueres gennem analyse af de mikroendolithiske sporfossiler.

\section{Acknowledgements}

This study is part of a long-term research project on bioerosion. Support by the German Research Foundation (DFG), Vo. 90/14 to K. Vogel and NOAA grant CMRC-94-24 to W. Kiene is gratefully acknowledged.

\section{References}

Bromley, R. G. \& Asgaard, U. 1993: Two bioerosion ichnofacies produced by early and late burial associated with sea-level change. Geologische Rundschau 82, 276-280.

Chazottes, V., Le Campion-Alsumard, T. \& Peyrot-Clausade, M. 1995: Bioreosion rates on coral reefs: interaction between macroborers, microborers and grazers (Moorea, French Polynesia). Palaeogeography, Palaeoclimatology, Palaeoecology 113, 189-198. 
Gektidis, M. 1997: Vorkommen, Ökologie und Taxonomie von Mikrobohrorganismen in ausgewählten Riffbereichen um die Inseln Lee Stocking Island, Bahamas, und One Tree Island, Australien. PhD-Thesis, unpubl., Johann Wolfgang Goethe Universität, 276 pp. Frankfurt am Main.

Glaub, I. (1994): Mikrobohrspuren in ausgewählten Ablagerungsräumen des europäischen Jura und der Unterkreide (Klassifikation und Palökologie). Courier Forschungs Institut Senckenberg 174, 324 pp. Frankfurt am Main.

Golubic, S., Perkins, R. D. \& Lukas, K. J. 1975: Boring microorganisms and microborings in carbonate substrates. In: Frey, R. W. (ed.) The Study of Trace Fossils, 229-259. New York: Springer.

Golubic, S., Campbell, S. E., Drobne, K., Cameron, B., Balsam, W. L., Cimerman, F. \& Dubois, L. 1984: Microbial endoliths: a benthic overprint in the sedimentary record, and a paleobathymetric cross-reference with foraminifera. Journal of Paleontology 58, 351-361.

Golubic, S., Campbell, S.E. \& Spaeth, C. 1983: Kunstharzausgüsse fossiler Mikroben-Bohrgänge. Der Präparator 29, 197-200.

Kiene, W., Radtke, G., Gektidis, M., Golubic, S. \& Vogel, K. 1995: Factors controlling the distribution of microborers in Bahamian reef environments. In: Schuhmacher, H., Kiene, W. \& Dullo, W. (eds) Factors controlling Holocene reef growth: an interdisciplinary approach. Facies 32, 174-188.

Le Campion-Alsumard, T., Golubic, S., \& Hutchings, P. 1995: Microbial endoliths in skeletons of live and dead corals: Porites lobata (Moorea, French Polynesia). Marine Ecology Progress Series 117, 149-157.

Radtke, G. 1991: Die mikroendolithischen Spurenfossilien im Alt-Teriär West-Europas und ihre palökologische Bedeutung. Courier Forschungsinstitut Senckenberg $138,1-185$.

Radtke, G., 1993: The distribution of microborings in molluscan shells from recent reef environments at Lee Stocking Island, Bahamas. Facies 29, 81-92.

Vogel, K., Bundschuh, M., Glaub, I., Hofmann, K., Radtke, G. \& Schmidt, H. 1995: Hard substrate ichnocoenose and their relations to light intensity and marine bathymetry. Neues Jahrbuch für Geologie und Paläontologie, Abhandlungen 195, 49-61.

Vogel, K., Kiene, W., Gektidis, M. \& Radtke, G. 1996: Scientific results from investigation of microbial borers and bioerosion in reef environments. In: Reitner, J., Neuweiler, F. \& Gunkel, F. (eds) Global and regional controls on biogenic sedimentation. I: Reef evolution, Göttinger Arbeiten zur Geologie und Paläontologie, Sb2, 139-143. Göttingen. 